\title{
Epidermal Growth Factor Receptor and K-RAS status in two cohorts of squamous cell carcinomas
}

\author{
Nancy Van Damme* +1 , Philippe Deron ${ }^{+2}$, Nadine Van Roy ${ }^{3}$, Pieter Demetter ${ }^{4}$, Alain Bols ${ }^{5}$, Jo Van Dorpe ${ }^{6}$, Filip Baert 7 , \\ Jean-Luc Van Laethem ${ }^{8}$, Franki Speleman ${ }^{3}$, Patrick Pauwels ${ }^{9}$ and Marc Peeters 1,10
}

\begin{abstract}
Background: With the availability of effective anti-EGFR therapies for various solid malignancies, such as non-cell small lung cancer, colorectal cancer and squamous cell carcinoma of the head and neck, the knowledge of EGFR and K-RAS status becomes clinically important. The aim of this study was to analyse EGFR expression, EGFR gene copy number and EGFR and K-RAS mutations in two cohorts of squamous cell carcinomas, specifically anal canal and tonsil carcinomas.

Methods: Formalin fixed, paraffin-embedded tissues from anal and tonsil carcinoma were used. EGFR protein expression and EGFR gene copy number were analysed by means of immunohistochemistry and fluorescence in situ hybridisation. The somatic status of the EGFR gene was investigated by PCR using primers specific for exons 18 through 21. For the K-RAS gene, $P C R$ was performed using exon 2 specific primers.

Results: EGFR immunoreactivity was present in 36/43 (83.7\%) of anal canal and in 20/24 (83.3\%) of tonsil squamous cell carcinomas. EGFR amplification was absent in anal canal tumours (0/23), but could be identified in 4 of 24 tonsil tumours.

From 38 anal canal specimens, 26 specimens were successfully analysed for exon 18, 30 for exon 19, 34 for exon 20 and 30 for exon 21. No EGFR mutations were found in the investigated samples. Thirty samples were sequenced for K-RAS exon 2 and no mutation was identified. From 24 tonsil specimens, 22 were successfully analysed for exon 18 and all 24 specimens for exon 19, 20 and 21. No EGFR mutations were found. Twenty-two samples were sequenced for K-RAS exon 2 and one mutation c.53C > A was identified.

Conclusion: EGFR mutations were absent from squamous cell carcinoma of the anus and tonsils, but EGFR protein expression was detected in the majority of the cases. EGFR amplification was seen in tonsil but not in anal canal carcinomas. In our investigated panel, only one mutation in the K-RAS gene of a tonsil squamous cell carcinoma was identified. This indicates that EGFR and K-RAS mutation analysis is not useful as a screening test for sensitivity to antiEGFR therapy in anal canal and tonsil squamous cell carcinoma.
\end{abstract}

\section{Background}

With the recent progress in molecular biology, the tumorigenesis of cancer is becoming better understood, and clinical management has improved. Epidermal growth factor receptor (EGFR) has been validated as a therapeutic target in several human tumours, including colorectal cancer (CRC), non-small cell lung cancer (NSCLC) and

\footnotetext{
* Correspondence: nancy.vandamme@ugent.be

1 Department of Hepato-Gastroenterology, Digestive Oncology Unit, Ghent University Hospital, De Pintelaan 185 1K12IE, 9000 Ghent, Belgium + Contributed equally

Full list of author information is available at the end of the article
}

squamous cell carcinoma of the head and neck (HNSCC). Ligand occupancy of EGFR activates the RAS/RAF/ MAPK, STAT and PI3K/Akt signalling pathways, which together modulate cellular proliferation, adhesion, angiogenesis and migration [1,2].

Monoclonal antibodies directed against the extracellular domain of EGFR and small molecule inhibitors of the tyrosine kinase domain of the receptor have been evaluated in the treatment of several solid tumours including CRC, NSCLC and HNSCC [3]. Cetuximab, a chimeric humanized antibody, and panitumumab, a fully humanized monoclonal antibody have shown efficacy in combi- 
nation with chemotherapy and also as monotherapeutic agents in CRC [4-6]. In NSCLC, approximately 85\% of patients who responded favourably to gefitinib or erlotinib, two FDA-approved small-molecule EGFR-tyrosinekinase inhibitors, were shown to have somatic mutations in the EGFR gene. Somatic EGFR mutations are primarily located in exons 18 through 21 around the ATP-binding pocket of the tyrosine kinase domain [7-10]. The most common mutations are short deletions in exon 19 affecting the amino acid sequence LREA (DelE746-A750) or a point mutation in exon 21 resulting in the amino acid change L858R. Increased EGFR gene copy number as determined by fluorescence in situ hybridisation (FISH) is known as a prognostic marker of progression-free survival and overall survival in HNSCC $[11,12]$.

Several reports indicate that the presence of $K-R A S$ mutations are a predictor of resistance to cetuximab and panitumumab therapy in metastatic colorectal cancer patients [13-16].

Cetuximab has been approved by the EMEA and FDA for HNSCC treatment. Recently, Vermorken et al. [17] described that cetuximab was effective in combination with platinum-based regimens for recurrent or metastatic squamous cell carcinoma of the head and neck.

Knowledge of the expression, amplification and mutation status of EGFR as well as downstream effectors such as $K-R A S$ would help us to better understand the response of cancer patients to molecular targeted therapy.

Anal canal carcinoma is a relatively rare gastrointestinal malignancy with an increasing rate of incidence. The estimated number of new cases in the United States in 2009 will reach about 5290 patients (2100 males and 3190 females). It is estimated that (of the afore-mentioned number) 260 males and 450 females will die from anal canal carcinoma [18]. It is now apparent that the development of anal cancer is associated with infection by human papillomavirus (HPV), usually sexually transmitted $[19,20]$. In the literature, few data regarding EGFR and $K$ $R A S$ status in squamous cell carcinoma of the anal canal is available [21-25].

HNSCC is the sixth most frequent cancer worldwide [26]. Despite current therapeutic modalities, many patients relapse or develop metastases, highlighting the need for new therapeutic targets. Several reports have described EGFR mutations in HNSCC patients, but these are heterogeneous, show ethnic differences in the frequency of occurrence, varying from $7 \%$ in Asians and to $0 \%$ to $4 \%$ in white patients $[11,12,27-32]$. In the literature, data regarding $K-R A S$ status in HNSCC from the western world is scarce [33].

The aim of the present study was to analyse EGFR expression, EGFR gene copy number and EGFR and $K$ $R A S$ mutational status in formalin-fixed, paraffin-embed- ded specimens from two cohorts of patients with squamous cell carcinoma, anal canal and tonsils.

\section{Methods}

\section{Patient and sample characteristics}

Formalin fixed, paraffin-embedded tissues from 51 squamous cell carcinomas of the anus and 24 squamous cell carcinoma of the tonsil were retrieved from the pathology departments of the participating institutions. The tissues were biopsied or resected between 1995 and 2006. Five micron thick sections were stained with haematoxylin and eosin for examination by light microscopy. The patient and sample characteristics are presented in Table 1. This study was approved by our local ethics committee. The number of evaluable cases for EGFR immunostaining, EGFR FISH, EGFR and K-RAS mutation analysis for the squamous cell carcinoma of the anus and tonsil are also presented in Table 1.

\section{EGFR immunohistochemistry}

EGFR immunostaining was performed using the Ventana system (Ventana Medical Systems Inc, Tucson, AZ). After deparaffinisation, five micron-thick sections were sequentially treated with inhibitor for 4 minutes and protease 1 for 6 minutes. Sections were then incubated with anti-EGFR mouse monoclonal IgG1 antibody (Clone 31G7, Zymed Laboratories, South San Francisco, CA, USA) for 32 minutes (1:100 dilution), after which they were incubated sequentially with amplifier A, amplifier B, biotinylated immunoglobulin, avidin-horseradish peroxidase and diaminobenzidine (DAB) for 8 minutes each. Sections were counterstained using haematoxylin for 6 minutes and bluing reagent for 2 minutes. All incubation steps were performed at $37^{\circ} \mathrm{C}$.

Specimens were evaluated microscopically. Stains were considered positive when membrane staining of any intensity occurred in tumour cells. According to their staining intensity, positive samples were defined as weak $(1+)$, moderate $(2+)$ or strong $(3+)$.

\section{EGFR-Fluorescence In Situ Hybridisation}

Dual colour FISH was performed with the Vysis LSI EGFR Dual Color probe (Abbott Molecular Inc., Des Plaines, IL, USA) which hybridises to the band region 7 p12 in SpectrumOrange and the centromere of chromosome 7 (7p11.1-q11.1, D7Z1 locus) in SpectrumGreen. FISH was carried out according to the protocol of the supplier.

For each slide, at least 20 neoplastic non-overlapping nuclei were scored for signals from both CEP7 and EGFR probes under the fluorescence microscope.

With a slight modification according to Cappuzzo et al. [34], patients were classified into five groups with ascending EGFR gene copy numbers. Briefly, disomy was defined as $\leq 2$ copies in $90 \%$ of cells, trisomy as 3 copies in 
Table 1: Patient and sample characteristics.

\begin{tabular}{|c|c|c|}
\hline & Anal Canal $(n=51)$ & Tonsils $(n=24)$ \\
\hline \multicolumn{3}{|l|}{ Age (years) } \\
\hline Median & 60 & 58 \\
\hline Range & $35-85$ & $43-80$ \\
\hline \multicolumn{3}{|l|}{ Gender (number) } \\
\hline Male & 25 & 18 \\
\hline Female & 26 & 6 \\
\hline \multicolumn{3}{|l|}{ Specimens (number) } \\
\hline Biopsies & 15 & 2 \\
\hline Resection & 36 & 22 \\
\hline \multicolumn{3}{|l|}{ Histological findings (number) } \\
\hline Well differentiated SCC & 17 & 5 \\
\hline Moderately differentiated SCC & 20 & 13 \\
\hline Poorly differentiated SCC & 14 & 6 \\
\hline \multicolumn{3}{|l|}{ Evaluable cases (number) for } \\
\hline EGFR immunostaining & 43 & 24 \\
\hline EGFR FISH & 23 & 24 \\
\hline \multicolumn{3}{|l|}{ EGFR mutation analysis } \\
\hline exon18 & 26 & 22 \\
\hline exon19 & 30 & 24 \\
\hline exon20 & 34 & 24 \\
\hline exon21 & 30 & 24 \\
\hline K-RAS mutation analysis & 30 & 22 \\
\hline
\end{tabular}

EGFR: Epidermal Growth Factor Receptor; FISH: Fluorescence In Situ Hybridisation; SCC: squamous cell carcinoma

$10-40 \%$ of the cells, low polysomy as $\geq 4$ copies in $10-40 \%$ of cells, high polysomy as $\geq 4$ copies in $\geq 40 \%$ of cells, and EGFR amplification was considered to be present if $>10 \%$ of the nuclei contained multiple EGFR signals and the EGFR/CEP7 ratio was $\geq 2$.

\section{EGFR and K-RAS mutation analysis}

Genomic DNA was isolated from $3 \times 50-\mu \mathrm{m}$ formalin fixed, paraffin-embedded tissues specimens. These sections were cut and incubated with $500 \mu \mathrm{l}$ of $1 \mathrm{X}$ phosphate-buffered saline (PBS) for $10 \mathrm{~min}$ at $80^{\circ} \mathrm{C}$. After centrifugation $(10 \mathrm{~min}-14000 \times \mathrm{g})$, paraffin and PBS were removed. DNA was isolated using the Centra Puregene tissue kit according to the manufacturers instructions (Qiagen GmBH, Hilden, Germany).

The somatic status of the EGFR gene was investigated by PCR using primers specific for exons 18-21, encompassing the tyrosine kinase domain. For the $K-R A S$ gene, PCR was performed using exon 2 specific primers. Subsequently, PCR fragments were analysed by direct sequencing in both sense and antisense direction. For ease of sequencing, M13 tails were attached to every primer pair.
Primer sequences were as follows: EGFR exon 18 forward primer: CCTGAGGTGACCCTTGTCTCTGTGTTCTT, reverse primer: GAGGCCTGTGCCAGGGACCTTA, EGFR exon 19 forward primer: CGCACCATCTCACAATTGCCAGTTA and reverse primer: AAAGGTGGGCCTGAGGTTCA, EGFR exon 20 forward primer: cacactgacgtgcctctcc and reverse primer: tatctccctcccotatct, EGFR exon 21 forward primer: CCCTCACAGCAGGGTCTTCTCTGT and reverse primer: TCAGG AAAATGCTGGCTGACCTA, K-RAS exon 2 forward primer: cgtcctgcaccagtaatatgc and reverse primer: GTATTAACCTTATGTGTGACA. The following PCR program was applied: $5 \mathrm{~min} 95^{\circ} \mathrm{C}, 30 \mathrm{sec} 95^{\circ} \mathrm{C}, 30 \mathrm{sec}$ $62^{\circ} \mathrm{C}, 30$ sec $68^{\circ} \mathrm{C}$ (with the last three steps repeated 42 times) and $7 \min 68^{\circ} \mathrm{C}$.

\section{Statistical analysis}

Data were analysed using SPSS 15.0 software. Correlations between EGFR protein expression and gene amplification were evaluated using Pearson's $\chi^{2}$ test. P-value < 0.05 was considered statistically significant. 


\section{Results}

EGFR expression in squamous cell carcinomas of the anal canal and tonsils

The immunohistochemical findings of EGFR expression are summarized in Table 2. EGFR expression analysis could be performed on 47 of 51 anal canal specimens, due to lack of sufficient material from the remaining four specimens. Immunoreactivity to EGFR was not interpretable in 4 of the 47 cases. From the remaining 43 cases, 36 showed immunoreactivity to EGFR (83.7\%). Among them, $29(67.4 \%)$ cases exhibited moderate $(2+)$ or strong $(3+)$ staining intensities (Figure 1). There was no correlation between EGFR expression and patient age $(\mathrm{P}=0.45)$ or differentiation grade $(\mathrm{P}=0.82)$.

EGFR expression analysis could be determined in all tonsil specimens. Twenty out of 24 showed immunoreactivity to EGFR (83.3\%). Among them, 10 (50\%) cases exhibited moderate $(2+)$ or strong $(3+)$ staining intensities. There was no correlation between EGFR expression and patient age $(\mathrm{P}=0.56)$ or differentiation grade $(\mathrm{P}=$ $0.52)$.

\section{EGFR gene copy number in squamous cell carcinoma of the} anal canal and tonsils

FISH analysis was performed on the same samples that were used for immunohistochemical analysis. However, 8 anal canal specimens could not be investigated due to technical problems and in 20 samples insufficient signal intensity was obtained for proper interpretation. Of the remaining 23 specimens, none showed EGFR gene amplification. EGFR disomy, trisomy, low polysomy and high polysomy were detected in 4, 11, 6 and 2 anal canal tissues, respectively (Table 3 ). The FISH patterns did not correlate with EGFR immunostaining $(\mathrm{P}>0.05)$.

All tonsil specimens could be investigated by FISH. Four specimens showed EGFR gene amplification (EGFR)
CEP7 ratio $\geq 2$ ) (Figure 2). In the remaining 20 tumours, disomy, trisomy and low polysomy were detected in 4, 13 and 3 tonsil tissues respectively (Table 3 ). Again, the FISH patterns did not correlate with EGFR immunostaining ( $\mathrm{P}$ $>0.05)$.

\section{EGFR and K-RAS mutation analysis}

In 10 of 51 anal canal specimens not enough material was available for DNA extraction. For three resection specimens sequence analysis failed for all investigated exons. Those same three specimens also failed FISH analysis indicating that most probably the fixation method of the available tissue did not allow for downstream DNA-based applications.

For EGFR mutation analysis exons 18 through 21 were examined. From the 38 anal canal specimens, 26 specimens were successfully analysed for exon 18, 30 for exon 19, 34 for exon 20 and 30 for exon 21. No EGFR mutations were found in the investigated samples. For $K-R A S$ gene mutation analysis exon 2 was examined. Out of the 38 anal canal specimens, 30 were sequenced, and no mutation was identified.

All tonsil specimens were representative for DNA extraction. From those specimens, 22 were successfully analysed for exon 18 and all 24 specimens were successfully analysed for exon 19, 20 and 21 . No EGFR mutations were found in the investigated samples. Out of the 24 specimens, 22 were sequenced for $K-R A S$ exon 2 mutation and one mutation c.53C > A (p.A18D) was identified (Figure 3). This $K-R A S$ mutated tonsil specimen showed no $E G F R$ gene amplification and exhibited weak EGFR immunostaining.

\section{Discussion}

With the availability of effective anti-EGFR therapies for various solid malignancies, such as NSCLC, CRC and

Table 2: Summary of Epidermal Growth Factor Receptor expression in anal canal and tonsil squamous cell carcinoma.

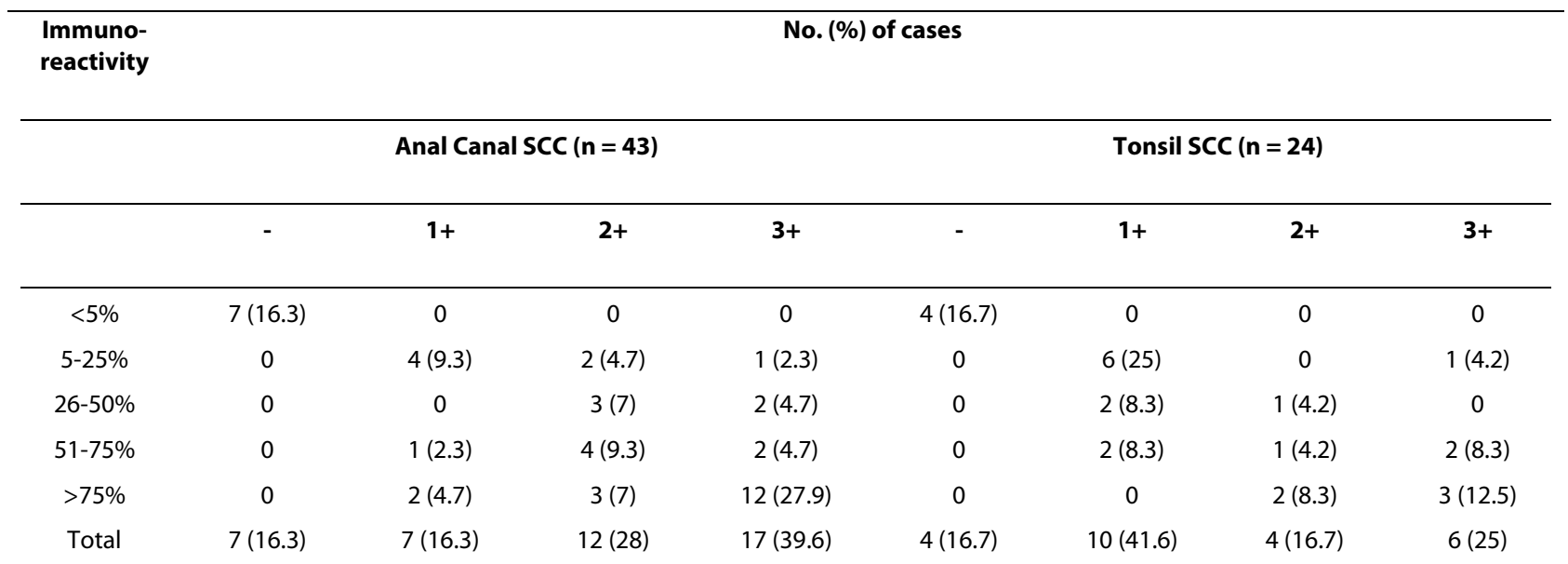

-: negative immunostaining 1+: weak immunostaining; $2+:$ moderate immunostaining; $3+$ : strong immunostaining; SCC: squamous cell carcinoma 

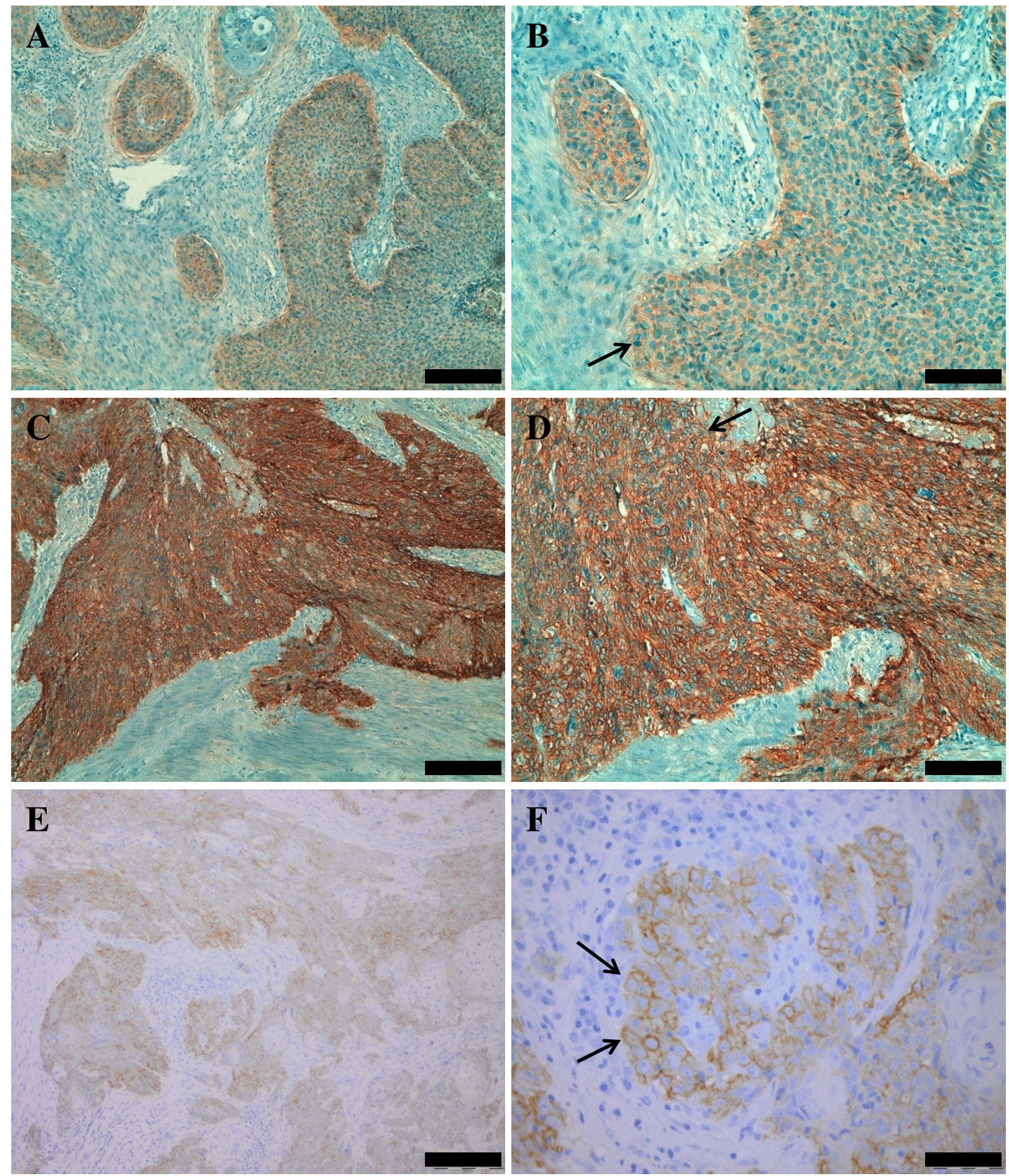

Figure 1 EGFR immunostaining. Anal canal squamous cell carcinoma, A to D. A. Weak immunostaining magnification $\times 100$; B. Weak immunostaining magnification $\times 200$; C. Strong immunostaining magnification $\times 100$; D. Strong immunostaining magnification $\times 200$. Tonsil squamous cell carcinoma, E and F. E. Immunostaining magnification x 100; F. Immunostaining magnification $\times 400$. Arrows indicate membrane staining. For $A, C$ and $E$, bar indicates $200 \mu \mathrm{m}$; B and D, $100 \mu \mathrm{m}$; and F $50 \mu \mathrm{m}$ 
Table 3: EGFR status in anal canal and tonsil squamous cell carcinoma.

\begin{tabular}{lcc}
\hline EGFR gene copy numbers & $\begin{array}{c}\text { Anal Canal SCC }(\mathbf{n}=\mathbf{2 3}) \\
\text { No. (\%) }\end{array}$ & $\begin{array}{c}\text { Tonsil SCC (n= 24) } \\
\text { No. (\%) }\end{array}$ \\
\hline Disomy & $4(17.4)$ & $4(16.7)$ \\
Trisomy & $11(47.8)$ & $13(54.1)$ \\
Low polysomy & $6(26.1)$ & $3(12.5)$ \\
High polysomy & $2(8.7)$ & 0 \\
Amplification & 0 & $4(16.7)$ \\
\hline SCC: squamous
\end{tabular}

HNSCC, the knowledge of EGFR and $K-R A S$ status becomes clinically important.

Currently, few data regarding EGFR expression in squamous cell carcinoma of the anus are available [2124]. Le et al. [21] found positive EGFR staining in all samples, Alvarez et al. [22] described EGFR immunoreactivity in 55\% of studied tumours, Zampino et al. [23] reported positivity in 7 of the 12 evaluable cases and in the cohort of Walker et al. [24] 96\% of the invasive anal canal cancers displayed EGFR immunoreactivity.

In the present study we showed immunohistochemical evidence of EGFR expression (i.e., at least $5 \%$ of tumour cells were positive) in $83.7 \%$ interpretable cases of squamous cell carcinoma of the anus. EGFR is overexpressed in most epithelial malignancies including HNSCC, ranging from 31 to $100 \%$ [32]. We showed EGFR expression in 20 out of 24 cases $(83.3 \%)$ of squamous cell carcinoma of the tonsils. The results of the different immunohistochemical studies were however not consistent. These differences could be explained by the use of

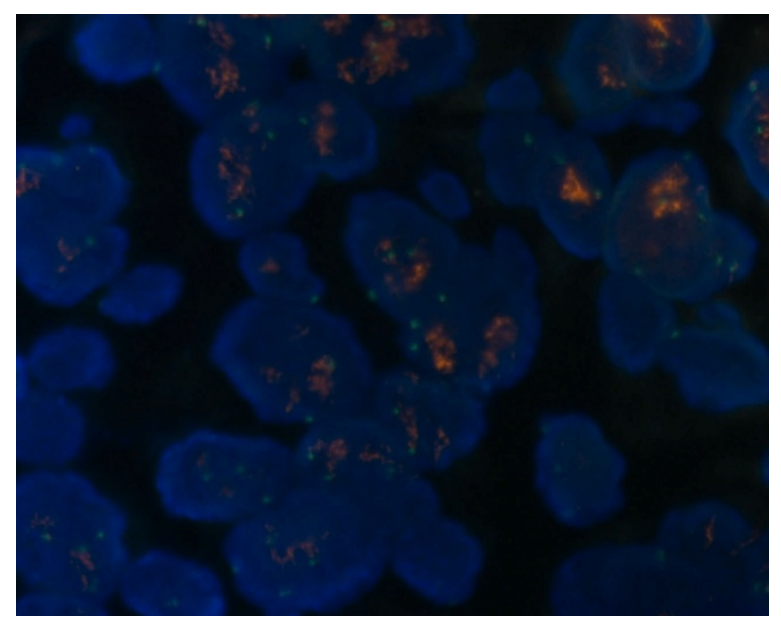

Figure 2 EGFR gene amplification by fluorescent in situ hybridization analysis in tonsil squamous cell carcinoma. FISH analysis was performed using SpectrumOrange EGFR probe (red signal) with a SpectumGreen CEP7 probe (green signal). different antibodies, immunohistochemical techniques and scoring systems. Variations in EGFR immunoreactivity are also dependent on the fixation procedure and the storage time of unstained tissue sections [35].

In the search for which patients will benefit from antiEGFR therapy, multiple studies investigating EGFR gene amplification have been performed. Increased EGFR gene copy number has been linked to poor prognosis in NSCLC [10] and HNSCC [11,12].

In our study, like Alvarez et al. [22] and Walker et al. [24], no EGFR gene amplification could be identified in anal canal squamous cell carcinoma samples. The prevalence of increased EGFR gene copy number in HNSCC varies in different studies, ranging between 13-58\% $[11,12,36]$. In the present study, four tonsil squamous cell carcinomas showed EGFR gene amplification, defined as a ratio of EGFR gene copies to CEP7 gene copies of at least two in more than $10 \%$ of tumour cells. We found EGFR protein expression was independent of EGFR gene amplification. Although EGFR gene amplification was identified in only four cases of tonsil squamous cell carcinoma, it was not possible to correlate this finding with patient outcome.

Approximately $85 \%$ of NSCLC patients who responded favourably to gefitinib or erlotinib were shown to have somatic mutations in the EGFR gene [7-10]. About $90 \%$ of EGFR mutations affect small regions of the gene usually within exons 18 to 21, which encode for the EGFR tyrosine kinase domain. Anti-EGFR treatment can prevent activation of downstream signalling pathways such as the PI3K/Akt, RAS/Erk and STAT pathways, resulting in the inhibition of cellular proliferation and induction of apoptosis.

No prior study has investigated EGFR gene mutation status in squamous cell carcinoma of the anus. In our panel, exons 18 to 21, encoding the EGFR tyrosine kinase domain were investigated. No mutations in the EGFR gene were identified which excludes overexpression being the result of the presence of mutations.

Up to date there have been few studies searching for mutations in HNSCC and the results are contradictory. 


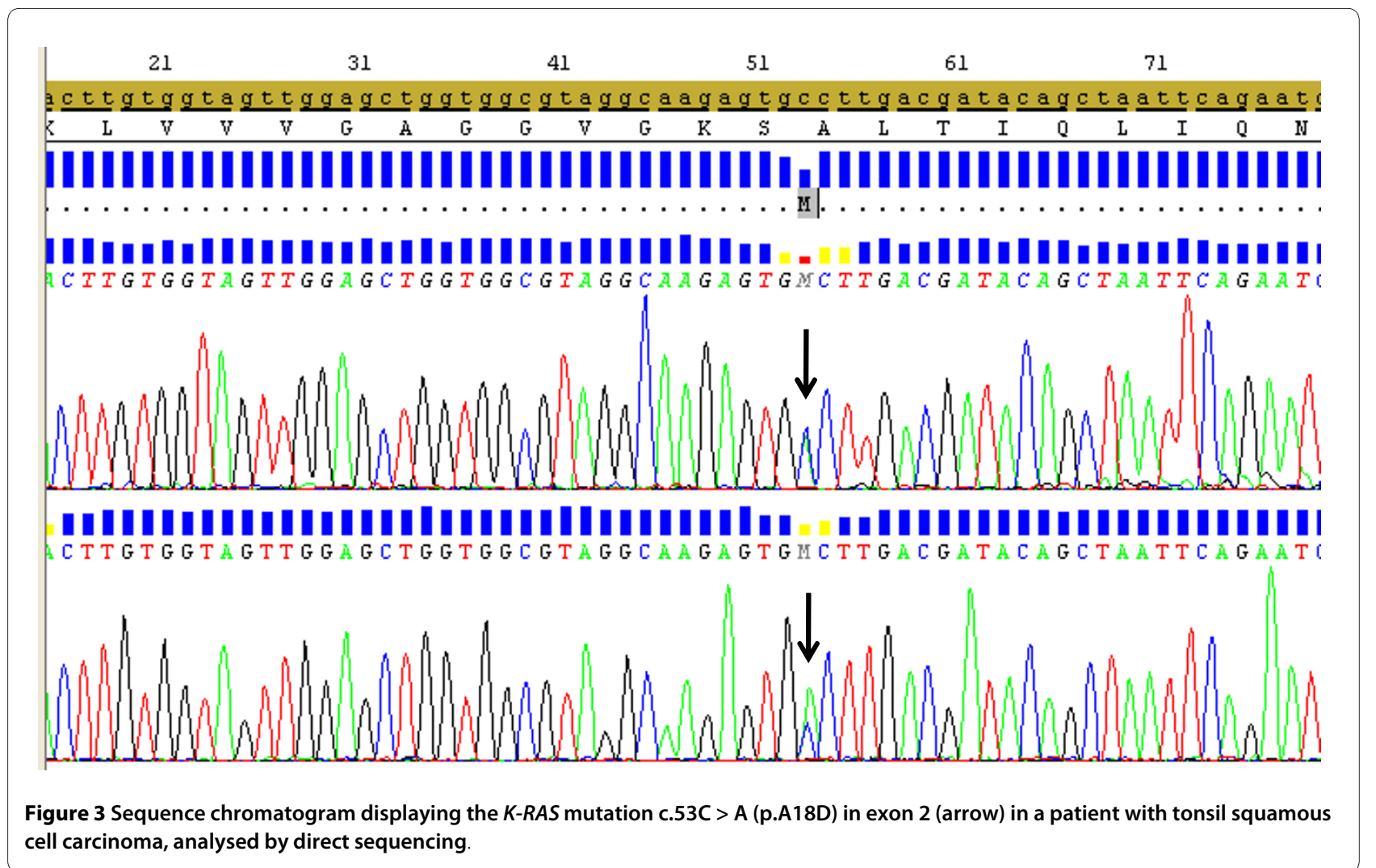

Lee et al. [27] found the mutation E746_A750del in 3 out of 41 Asian HNSCC patients (7.3\%) and $\mathrm{Na}$ et al. [28] described several changes in 17 out of 108 Korean HNSCC patients (15.7\%). Recently, one report analysed 91 Japanese HNSCC and 12 HNSCC cell lines for mutations in EGFR, ErbB2 and K-RAS. Only one silent mutation, C836T was found in exon 21 of EGFR in the UTSCC-16A cell line. No other mutations were found [29].

Chung et al. [11] reported that no EGFR-activating mutations were found in 86 tumour samples from 82 American HNSCC patients. Temam et al. [12] also failed to detect any EGFR mutation in 134. French and American HNSCC patients. Lemos-Gonzalez et al. [30] analysed EGFR tyrosine kinase mutations from 31 Spanish HNSCC patients and none displayed a somatic EGFR mutation. Loeffler-Ragg et al. [31] screened 100 Caucasian HNSCC patients and only one displayed a novel, somatic EGFR missense mutation. From the same group Schwentner et al. [32] reported a rare EGFR mutation p. G796S in 2 out of 127 Austrian patients.

In our study, no EGFR mutations were found in tonsil squamous cell carcinoma, which confirms that EGFR kinase mutations are rare in Caucasian patients. It is known from studies in other tumour types (e.g. NSCLC) that somatic mutations in the tyrosine kinase domain of EGFR are much more common in adenocarcinomas than in squamous cell carcinoma [37]. Although the presence of activating mutations was first related to the ethnicity, it is now known that the frequency of EGFR mutations in NSCLC patients is not different in Western or Asian populations when the smoking habit is taken into account [9,38]. Although it is not clear that the pattern of EGFR mutations in NSCLC could be directly translated to HNSCC, the low frequency of EGFR mutations, and the fact that all but three patients included in our study are significant current smokers, could explain the absence of EGFR mutations in our subset of patients.

HPV-infection is a risk factor for head and neck, anal canal, cervical and vulvar squamous cell carcinomas. Recently, in head and neck and vulvar squamous cell carcinoma, EGFR mutations and protein overexpression were predominantly HPV-negative and associated with poorer prognoses [28,39]. Recently, Walker et al. [24] investigated EGFR expression in anal HPV-infected squamous intraepithelial lesions and/or invasive cancers. In both HIV-positive and HIV-negative patients the EGFR immunostaining increased from condyloma acuminata (HPV6 and 11 infected) through anal intraepithelial neoplasia 1,2 and 3 till invasive squamous carcinoma (both infected with oncogenic HPV), highlighting the effects of oncogenic HPVs. Also, HIV-positive status contributes to augment EGFR expression levels involved in carcinogenesis. However, in our study the HPV-status and HIV-status was not systematically established. So, it 
would be of interest in future works to investigate both the HPV-status and HIV-status in anal squamous lesions.

Activating mutations in the $K-R A S$ gene, which result in EGFR-independent activation of the mitogen-activated protein kinase pathway, are found in $35 \%$ of patients with CRC and in 15 to $30 \%$ of patients with NSCLC. The mutations are most frequently found in codon 12 and 13 of exon 2 of the $K-R A S$ gene and are usually mutually exclusive with EGFR mutations [3]. Recently, several reports have indicated that $K-R A S$ mutations are an important predictor of resistance to cetuximab [13-15] and panitumumab therapy [16] in metastatic colorectal cancer patients and are associated with an unfavourable prognosis.

Hiorns et al. [40] screened for activating mutations of the ras oncogene family in anal carcinoma using DNA amplified in vitro by PCR. Mutations were seen in two cases, both in Ki-ras codon 12. In our anal canal panel, exon 2 of $K-R A S$ was investigated and no mutations were found. Mutations of the RAS family constitute one of the changes during cancer development. However, these mutations differ based on cancer type and ethnicity of the patients. In HNSCC patients from the western world these mutations were relatively infrequent [33] while in India they are very common [41]. In our tonsil carcinoma panel, one $K-R A S$ mutation, c.53C > A (p.A18D) was identified. This specimen showed no EGFR gene amplification and had weak EGFR immunostaining. To look for the occurrence of this mutation, the COSMIC databank http://www.sanger.ac.uk/genetics/CGP/cosmic was screened and the c.53C > A mutation has been described in one Japanese lung adenocarcinoma patient [42].

\section{Conclusions}

We can state that EGFR mutations were absent from squamous cell carcinoma of the anus and tonsils, but that EGFR protein expression was detected in the majority of the cases. EGFR amplification was seen in tonsil but not in anal canal carcinomas. In our investigated panel, only one mutation in the $K-R A S$ gene of a tonsil squamous cell carcinoma was identified, indicating that EGFR and $K$ $R A S$ mutations are infrequent in this cohort of squamous cell carcinomas. This indicates that EGFR and K-RAS mutation analysis is not useful as a screening test for sensitivity to anti-EGFR therapy in anal canal and tonsil squamous cell carcinoma.

\section{Competing interests}

The authors declare that they have no competing interests.

\section{Authors' contributions}

NVD participated in the design and coordination of the study, performed the statistical analysis and drafted the manuscript. PD provided clinical samples and helped to draft the manuscript. NVR participated in the design of the study, performed the mutation analysis and helped to draft the manuscript. PDM provided clinical samples and clinicopathological data and revised the manuscript. $A B$ provided clinical samples and clinicopathological data. JVD provided clinical samples and clinicopathological data. FB provided clinical samples and clinicopathological data and revised the manuscript. JLVL provided clinical samples and clinicopathological data and revised the manuscript. FS performed the mutation analysis and revised the manuscript. PP participated in the design of the study, performed the immunohistochemistry and FISH analysis and helped to draft the manuscript. MP conceived of the study, participated in the design and revised the manuscript. All authors read and approved the manuscript.

\section{Acknowledgements}

We thank Justine Nuytens and Bart Matthys for their excellent technical assistance with mutation analysis, immunohistochemistry and FISH analysis. This work was supported by a grant of 'Centrum voor studie en behandeling van Gezwelziekten - Gent', Belgium and an unrestricted research grant from Wyeth Pharmaceuticals.

\section{Author Details}

1'Department of Hepato-Gastroenterology, Digestive Oncology Unit, Ghent University Hospital, De Pintelaan 185 1K12IE, 9000 Ghent, Belgium, 2Department of Head and Neck Surgery, Ghent University Hospital, De Pintelaan 185, 9000 Ghent, Belgium, ${ }^{3}$ Centre for Medical Genetics, Ghent University Hospital, De Pintelaan 185, 9000 Ghent, Belgium, ${ }^{4}$ Department of Pathology, Université libre de Bruxelles, Route de Lennik 808, 1070 Brussels, Belgium, 5 Department of Oncology, AZ Sint-Jan Brugge, Ruddershove 10, 8000 Bruges, Belgium, ${ }^{6}$ Department of Pathology, Heilig Hart Ziekenhuis Roeselare, Wilgenstraat 2, 8800 Roeselare, Belgium, 7 Department of Gastroenterology, Heilig Hart Ziekenhuis Roeselare, Wilgenstraat 2, 8800 Roeselare, Belgium, ${ }^{8}$ Department of Gastroenterology, Université libre de Bruxelles, Route de Lennik 808, 1070 Brussels, Belgium, ${ }^{9}$ Department of Pathology, Ghent University Hospital, De Pintelaan 185, 9000 Ghent, Belgium and ${ }^{10} \mathrm{MP}$ is a Senior Clinical Investigator Research Foundation - Flanders

Received: 21 December 2009 Accepted: 11 May 2010

Published: 11 May 2010

\section{References}

1. Medelsohn J, Baselga J: Epidermal growth factor receptor targeting in cancer. Semin Oncol 2006, 33:369-385.

2. Hynes NE, Lane HA: ERBB receptors and cancer: The complexity of targeted inhibitors. Nat Rev Cancer 2005, 5:341-354.

3. Ciardiello F, Tortora G: EGFR antagonists in cancer treatment. N Eng/ J Med 2008, 358:1160-1174

4. Cunningham D, Humblet $Y$, Siena S, Khayat D, Bleiberg $H$, Santoro A, Bets D, Mueser M, Harstrick A, Verslype C, Chau I, Van Cutsem E: Cetuximab monotherapy and cetuximab plus irinotecan in irinotecan-refractory metastatic colorectal cancer. N Engl J Med 2004, 351:337-345.

5. Saltz LB, Meropol NJ, Loehrer PJ Sr, Needle MN, Kopit J, Mayer RJ: Phase II trial of cetuximab in patients with refractory colorectal cancer that expresses the epidermal growth factor receptor. J Clin Oncol 2004, 22:1201-1208.

6. Van Cutsem E, Peeters M, Siena S, Humblet Y, Hendlisz A, Neyns B, Canon JL, Van Laethem JL, Maurel J, Richardson G, Wolf M, Amado RG: Openlabel phase III trial o panitumumab plus best supportive care compared with best supportive care alone in patients with chemotherapy-refractory metastatic colorectal cancer. J Clin Oncol 2007, 25:1658-1664.

7. Lynch TJ, Bell DW, Sordella R, Gurubhagavatula S, Okimoto RA, Brannigan BW, Harris PL, Haserlat SM, Supko JG, Haluska FG, Louis DN, Christiani DC, Settleman J, Haber DA: Activating mutations in the epidermal growth factor receptor underlying responsiveness of non-small-cell lung cancer to gefitinib. N Engl J Med 2004, 350:2129-2139.

8. Paez JG, Janne PA, Lee JC, Tracy S, Greulich H, Gabriel S, Herman P, Kaye FJ, Lindeman N, Boggon TJ, Naoki K, Sasaki H, Fujii Y, Eck MJ, Sellers WR, Johnson BE, Meyerson M: EGFR mutations in lung cancer: correlation with clinical response to gefitinib therapy. Science 2004, 304:1497-1500.

9. Pao W, Miller V, Zakowski M, Doherty J, Politi K, Sarkaria I, Singh B, Heelan R, Rusch V, Fulton L, Mardis E, Kupfer D, Wilson R, Kris M, Varmus H: EGF receptor gene mutations are common in lung cancers from "never smokers" and are associated with sensitivity of tumors to gefitinib and erlotinib. Proc Natl Acad Sci USA 2004, 101:13306-13311. 
10. Sequist LV, Joshi VA, Janne PA, Bell DW, Fidias P, Lindeman NL, Louis DN, Lee JC, Mark EJ, Longtine J, Verlander P, Kucherlapati R, Meyerson M, Haber DA, Johnson BE, Lynch TJ: Response to treatment and survival of patients with non-small cell lung cancer undergoing somatic EGFR mutation testing. Oncologist 2007, 12:90-98.

11. Chung CH, Ely K, McGavran L, Varella-Garcia M, Parker J, Parker N, Jarrett C, Carter J, Murphy BA, Netterville J, Burkey BB, Sinard R, Cmelak A, Levy S, Yarbrough WG, Slebos RJC, Hirsh FR: Increased epidermal growth factor receptor gene copy number is associated with poor prognosis in head and neck squamous cell carcinomas. J Clin Oncol 2006, 24:4170-4176.

12. Temam S, Kawaguchi H, El-Naggar AK, Jelinek J, Tang H, Liu DD, Lang W, Issa J-P, Lee JJ, Mao L: Epidermal growth factor receptor copy number alterations correlate with poor clinical outcome in patients with head and neck squamous cancer. J Clin Oncol 2007, 25:2164-2170.

13. Lievre A, Bachet JB, Le Corre D, Boige V, Landi B, Emile J-F, Cote J-F, Tomasic G, Penna C, Ducreux M, Rougier P, Penault-Llorca F, Laurent-Puig $P$ : KRAS mutation status is predictive of response to cetuximab therapy in colorectal cancer. Cancer Res 2006, 66:3992-3995.

14. Khambata-Ford S, Garrett CR, Meropol NJ, Basik M, Harbison CT, Wu S, Wong TW, Huang X, Takimoto CH, Godwin AK, Tan BR, Krishnamurthi SS, Burris III HA, Poplin EA, Hidalgo M, Baselga J, Clark EA, Mauro DJ: Expression of epiregulin and amphiregulin and K-ras mutation status predict disease control in metastatic colorectal cancer patients treated with cetuximab. J Clin Oncol 2007, 25:3230-3237.

15. De Roock W, Piessevaux H, De Schutter J, Janssens M, De Hertogh G, Personeni N, Biesmans B, Van Laethem J-L, Peeters M, Humblet Y, Van Cutsem E, Tejpar S: KRAS wild-type state predicts survival and is associated to early radiological response in metastatic colorectal cancer treated with cetuximab. Ann Oncol 2008, 19:508-515.

16. Amado RG, Wolf M, Peeters M, Van Cutsem E, Siena S, Freeman D, Juan T, Sikorski R, Suggs S, Radinsky R, Patterson SD, Chang DD: Wild-type KRAS is required for panitumumab efficacy in patients with metastatic colorectal cancer: results from a randomised, controlled trial. J Clin Oncol 2008, 26:1626-1634

17. Vermorken JB, Mesia R, Rivera F, Remenar E, Kawecki A, Rottey S, Erfan J, Zabolotnyy D, Kienzer H-R, Cupissol D, Peyrade F, Benasso M, Vynnychenko I, De Raucourt D, Bokemeyer C, Schueler A, Amellal N, Hitt R: Platinum-based chemotherapy plus cetuximab in head and neck cancer. N Engl J Med 2008, 359:1116-1127.

18. Jemal A, Siegel R, Ward E, Hao Y, Xu J, Murray T, Thun MJ: Cancer statistics. CA Cancer J Clin 2009, 59:225-249.

19. Sobhani I, Vuagnat A, Walker F, Vissuzaine C, Mirin B, Hervatin F, Marmuse JP, Crémieux AC, Carbon C, Henin D, Lehy T, Mignon M: Prevalence of high-grade dysplasia and cancer in the anal canal in human papillomavirus-infected individuals. Gastroenterology 2001, 120:857-866.

20. Daling JR, Madeleine MM, Johnson LG, Schwartz SMm, Shera KA Wurscher MA, Carter JJ, Porter PL, Gallowy DA, McDougall JK: Human papillomavirus, smoking and sexual practices in the etiology of anal cancer. Cancer 2004, 101:270-280

21. Le LH, Chetty R, Moore MJ: Epidermal growth factor receptor expression in anal canal carcinoma. Am J Clin Pathol 2005, 124:20-23.

22. Alvarez G, Perry A, Tan BR, Wang HL: Expression of epidermal growth factor receptor in squamous cell carcinomas of the anal canal is independent of gene amplification. Mod Pathol 2006, 19:942-949.

23. Zampino MG, Magni E, Sonzogni A, Renne G: K-ras status in squamous cell anal carcinoma (SCC): it's time for targeted-oriented treatment? Cancer Chemother Pharmacol 2009, 65:197-199.

24. Walker F, Abramowitz L, Benabderrahmane D, Duval X, Descatoire V, Hénin D, Lehy T, Aparicio T: Growth factor receptor expression in anal squamous lesions: modifications associated with oncogenic human papillomavirus and human immunodeficiency virus. Hum Pathol 2009, 40:1517-1527.

25. Lukan N, Ströbel P, Willer A, Kripp M, Dinter D, Mai S, Hochhaus A, Hofheinz RD: Cetuximab-based treatment of metastatic anal cancer: correlation of response with KRAS mutational status. Oncology 2009, 77:293-299.

26. Argiris A, Karamouzis MV, Raben D, Ferris RL: Head and neck cancer. Lancet 2008, 17:1695-1709.

27. Lee JW, Soung YH, Kim SY, Nam HK, Park WS, Nam SW, Kim NS, Sun DI, Lee YS, Jang JJ, Lee JY, Yoo NJ, Lee SH: Somatic mutations of EGFR gene in squamous cell carcinoma of the head and neck. Clin Cancer Res 2005, 11:2879-2882.

28. Na II, Kan HJ, Cho SY, Koh JS, Lee JK, Lee BC, Lee GK, Lee YS, Yoo HJ, Ryoo $B-Y$, Yang SH, Shim YS: EGFR mutations and human papillomavirus is squamous cell carcinoma of tongue and tonsil. Eur J Cancer 2007, 43:520-526

29. Sheikh Ali MAL, Gunduz M, Nagatsuka H, Gunduz E, Cengiz B, Fukushima K, Beder LB, Demircan K, Fujii M, Yamanaka N, Shimizu K, Grenman R, Nagai $\mathrm{N}$ : Expression and mutation analysis of epidermal growth factor receptor in head and neck squamous cell carcinoma. Cancer Sci 2008, 99:1589-1594.

30. Lemos-Gonzalez Y, Paez de la Cadena M, Rodriguez-Berrocal FJ, Rodriguez-Pineiro AM, Pallas E, Valverde D: Absence of activating mutations in the EGFR kinase domain in Spanish head and neck cancer patients. Tumour Biol 2007, 28:273-279.

31. Loeffler-Ragg J, Witsch-Baumgartner M, Tzankov A, Hilbe W, Schwentner I, Sprinzl GM, Utermann G, Zwierzina H: Low incidence of mutations in EGFR kinase domain in Caucasian patients with head and neck squamous cell carinoma. Eur J Cancer 2006, 42:109-111.

32. Schwentner I, Witsch-Baumgartner M, Sprinzl GM, Krugmann J, Tzankov A, Jank S, Zwierzina H, Loeffler-Ragg J: Identification of the rare EGFR mutation p. G796S as somatic and germline mutation in white patients with squamous cell carcinoma of the head and neck. Head Neck 2008, 30:1040-1044

33. Yarbrough WG, Shores C, Witsell DL, Weissler MC, Fidler ME, Gilmer TM: ras mutations and expression in head and neck squamous cell carcinomas. Laryngoscope 1994, 104:1337-1347

34. Cappuzzo F, Hirsch FR, Rossi E, Bartolini S, Ceresoli GL, Bemis L, Haney J, Witta S, Danenberg K, Domenichini I, Ludovini V, Magrini E, Gregorc V, Doglioni C, Sidoni A, Tonato M, Franklin WA, Crino L, Bunn PA Jr, VarellaGarcia M: Epidermal growth factor receptor gene and protein and gefitinib sensitivity in non-small-cell lung cancer. J Natl Cancer Inst 2005, 97:643-655.

35. Atkins D, Reiffen KA, Tegtmeier CL, Winther $\mathrm{H}$, Bonato MS, Storkel S: Immunohistochemical detection of EGFR in paraffin-embedded tumor tissues: variation in staining intensity due to choice of fixative and storage time of tissue sections. J Histochem Cytochem 2004, 52:893-901.

36. Egloff AM, Grandis JR: Improving response rates to EGFR-targeted therapies for head and neck squamous cell carcinoma: candidate predictive biomarkers and combination treatment with Scr inhibitors. J Oncol 2009, 2009:896407.

37. Sueoka-Aragane N, Imai K, Komiya K, Sato A, Tomimasu R, Hisatomi T, Sakuragi T, Mistuoka M, Hayashi S, Nakachi K, Sueoka E: Exon 19 of EGFR mutation in relation to the CA-repeat polymorphism in intron 1. Cancer Sci 2008, 99:1180-1187.

38. Riely GJ, Pao W, Pham D, Li AR, Rizvi N, Venkatraman ES, Zakowski MF, Kris MG, Ladanvi M, Miller VA: Clinical course of patients with non-small cell lung cancer and epidermal growth factor receptor exon 19 and exon 21 mutations treated with gefitinib or erlotinib. Clin Cancer Res 2006, $12: 839-844$

39. Growdon WB, Bosivert SL, Akhavanfard S, Oliva E, Dias-Santagata DC, Kojiro S, Horowitz NC, lafrate J, Borger DR, Rueda BR: Decreased survival in EGFR gene amplified vulvar carcinoma. Gynecol Oncol 2008, 111:289-297.

40. Hiorns LR, Scholefield JH, Palmer JG, Shepherd NA, Kerr IB: Ki-ras oncogene mutations in non-HPV-associated anal carcinoma. J Pathol 1990, 161:99-103

41. Das N, Majumder J, DasGupta UB: Ras gene mutations in oral cancer in eastern India. Oral Onco 2000, 36:76-80.

42. Suzuki Y, Orita M, Shiraishi M, Hayashi K, Sekiya T: Detection of ras gene mutation in human lung cancers by single-strand conformation polymorphism analysis of polymerase chain reaction products. Oncogene 1990, 5:1037-1043.

\section{Pre-publication history}

The pre-publication history for this paper can be accessed here: http://www.biomedcentral.com/1471-2407/10/189/prepub

doi: $10.1186 / 1471-2407-10-189$

Cite this article as: Van Damme et al., Epidermal Growth Factor Receptor and K-RAS status in two cohorts of squamous cell carcinomas BMC Cancer 2010, 10:189 